\title{
Peningkatan Partisipasi Belajar Siswa Kelas IV Dalam Pembelajaran PAI Dengan Strategi True or False Di SDN 38 Sungai Limau Kabupaten Padang Pariaman
}

\section{Hasnibar}

\begin{abstract}
This research is based on the lack of student's participacion in learning religion subject, including do discussion, propose the ideas, or conclude the material. It is caused by "speech method" that teacher used to do in learning, so that students got the low score for this subject. This research is aimed to improve student's participation in learning religion subject by implementing True of False method. This is classroom action research with subject are students grade IV in SDN 38 Sungai Limau Kabupaten Padang Pariaman. Data were obtained through observation on student's participation in learning, observation on teacher's activities, and final test for students. Data were analyzed quantitatively and qualitatively. Based on the result of this research, student's participation in learning: (1) percentage of students in doing discussion is $60 \%$ for cycle I and $85 \%$ for cycle II; (2) percentage of students in proposing ideas is $50 \%$ for cycle I and 75\% for cycle II; and (3) percentage of students in concluding the lesson is 30\% for cycle I and $72.5 \%$ for cycle II. Thus, learning of religion subject that implement the True or False strategy can improve student's participation in learning.
\end{abstract}

Keyword: participation in learning, true or false strategy, PAI learning

\section{PENDAHULUAN}

Pendidikan dapat mengembangkan berbagai potensi yang dimiliki seorang individu secara optimal, yaitu pengembangan potensi individu yang setinggi-tingginya dalam aspek fisik, intelektual, emosional, sosial, spiritual, sesuai dengan tahap perkembangan serta karakteristik lingkungan fisik dan lingkungan sosial budaya di mana dia hidup. Seperti diketahui dalam dunia pendidikan, guru adalah seorang pendidik, pembimbing, pelatih, dan pengembang kurikulum yang dapat menciptakan kondisi dan suasana pembelajaran yang kondusif, yaitu suasana belajar yang menyenangkan, menarik, memberi rasa aman, memberikan ruang pada siswa untuk berpikir aktif, kreatif, dan inovatif dalam mengeksplorasi dan mengelaborasi kemampuannya.

Pendidikan yang baik, sebagaimana yang diharapkan masyarakat modern dewasa ini dan sifatnya selalu menantang, mengharuskan adanya pendidik yang profesional. Hal ini berarti bahwa di masyarakat diperlukan pemimpin yang baik, di rumah diperlukan orangtua yang baik dan di sekolah dibutuhkan guru yang profesional. Akan tetapi, dengan ketiadaan pegangan tentang persyaratan pendidikan profesional, maka hal ini menyebabkan timbulnya bermacam-macam tafsiran orang tentang arti guru yang baik, tegasnya guru yang profesional. Pembelajaran PAI diupayakan agar dapat mempersiapkan siswa memiliki kepribadian yang mantap. PAI membantu siswa agar memiliki sikap menghormati dan tenggang rasa terhadap sesama, Pembelajaran PAI akan dapat dipahami dan nilai-nilai yang diperoleh dari PAI dapat diamalkan dalam kehidupan oleh siswa, maka peran guru sangat dituntut untuk dapat menciptakan proses pembelajaran yang menyenangkan, bermakna, menantang, serta dapat mengaktifkan belajar siswa.

Berdasarkan observasi yang peneliti lakukan di SD Negeri 38 Sungai Limau, Kabupaten Padang Pariaman, khususnya di kelas IV, dalam proses pembelajaran peneliti melihat hanya 2 siswa yang mengajukan pertanyaan, dan tidak ada siswa mengemukakan pendapatnya. Siswa merasa jenuh mendengarkan penjelasan dari guru karena dalam proses pembelajaran guru lebih cenderung menggunakan metode ceramah. Kemudian dilanjutkan dengan pembelajaran menggunakan metode diskusi. Hanya sebagian siswa yang ikut serta dalam diskusi dan sebagiannya lagi hanya mendengar atau menonton saja. Begitu juga dilihat pada akhir pembelajaran tidak ada siswa yang bisa menyimpulkan pelajaran tersebut.

Hasil wawancara dengan guru kelas IV diketahui bahwa dalam pembelajaran PAI terdapat 3 orang siswa yang sering tidak memperhatikan guru. Mereka sering bercerita dengan teman sebangkunya, bahkan sibuk dengan kegiatannya sendiri. Selain itu, jika dilihat dari hasil ujian mid semester siswa juga masih belum 
mencapai Kriteria Ketuntasan Minimal (KKM) 70 dan ada beberapa orang siswa yang belum mencapai KKM. Dari 20 orang siswa, masih ada 10 orang siswa dengan nilainya kurang dari 70 . Rendahnya nilai siswa di antaranya disebabkan oleh kurang tepatnya metode yang digunakan oleh guru, juga ketidaktersediaan sumber belajar. Hasil nilai PAI mid Semester 1 Tahun Ajaran 2013/2014 dapat dilihat pada Tabel 1.

\section{Tabel 1}

Nilai Ujian Mid Semester 1 Siswa Kelas IV SD Negeri 38 Sungai Limau Tahun Ajaran 2013/2014

\begin{tabular}{cccccc}
\hline \multirow{2}{*}{ Kelas } & \multirow{2}{*}{ Rata-rata } & \multicolumn{2}{c}{ Tuntas } & \multicolumn{2}{c}{ Tidak Tuntas } \\
\cline { 3 - 6 } & & $\begin{array}{c}\text { Jumlah } \\
\text { (orang) }\end{array}$ & $\%$ & $\begin{array}{c}\text { Jumlah } \\
\text { (orang) }\end{array}$ & $\%$ \\
\cline { 3 - 6 } IV & 64,35 & 10 & 41,93 & 10 & 58,06 \\
\hline
\end{tabular}

Rendahnya hasil belajar yang diperoleh peserta didik pada mata pelajaran PAI seperti pada Tabel di atas, disebabkan kurangnya keterampilan guru dalam memilih strategi yang sesuai dengan materi pembelajaran. Hal lainnya guru juga masih dominan menggunakan metode pembelajaran secara konvensional dan kurang melibatkan peserta didik, sehingga peserta didik kurang aktif dan kurang memiliki partisipasi dalam proses pembelajaran. Dalam hal ini guru perlu memahami karakteristik materi, peserta didik, dan metode mengajar dalam proses pembelajaran. Dengan demikian, proses pembelajaran akan lebih variatif, inovatif, dan konstruktif dalam merekonstruksi wawasan pengetahuan dan implementasinya sehingga dapat meningkatkan partisipasi peserta didik. Untuk mewujudkan itu semua sangat dipengaruhi oleh iklim pembelajaran yang kondusif. Dalam menciptakan iklim pembelajaran yang kondusif diperlukan kemampuan dan keterampilan guru dalam memilih strategi pembelajaran yang cocok digunakan dalam penyampaian materi, sehingga peserta didik terlibat aktif dalam proses pembelajaran. Pemilihan strategi pembelajaran yang tepat juga dapat meningkatkan gairah belajar peserta didik.

Banyak strategi pembelajaran yang dapat dipilih oleh seorang guru dalam menyampaikan materi pelajaran untuk meningkatkan partisipasi peserta didik dalam proses pembelajaran, salah satunya strategi pembelajaran aktif True or False. Strategi True or False memiliki makna bahwa: "Kegiatan kolaboratif ini juga merangsang keterlibatan langsung dalam materi pelajaran. Strategi tersebut untuk mengembangkan bangunan tim (team building), berbagi pengetahuan dan belajar langsung" (Silberman, 2009:24). Selain itu Zaini, dkk. (2005:24) menyatakan strategi True or False adalah "Aktivitas kolaboratif yang dapat mengajak siswa untuk terlibat ke dalam materi pelajaran dengan segera. Strategi ini menumbuhkan kerjasama tim, berbagi pengetahuan dan belajar secara langsung". Hal ini karena dengan Strategi Pembelajaran Aktif True or False kepada siswa dapat merangsang partisipasi belajar siswa dalam menjawab pernyataan, mengemukakan pendapat dan mendengarkan diskusi secara klasikal. Berikut adalah langkah-langkah dari strategi pembelajaran True or False:

a) Buatlah sebuah daftar pernyataan yang berkaitan dengan materi pelajaran, setengah darinya benar dan setengah yang lain salah.

b) Tulislah masing-masing pernyatan dalam suatu kartu indeks yang terpisah. Pastikan ada banyak kartu sebanyak peserta didik yang ada di kelas. (jika ada satu nomor ganjil dari peserta didik yang ganjil, buatlah satu kartu untuk guru).

c) Bagikan satu kartu kepada masing-masing peserta didik. Beritahu seluruh kelas bahwa misi mereka adalah menetapkan kartu-kartu mana yang benar dan mana yang salah.

d) Jelaskan bahwa mereka bebas menggunakan metode yang mereka inginkan untuk mencapai tugas tersebut.

e) Ketika mata pelajaran selesai, suruhlah masing-masing siswa untuk membacakan kartunya dan dapatkan opini kelas mengenai apakah pernyataan itu benar atau salah. Berilah pandangan atau pendapat minoritas,

f) Berilah tanggapan balik tentang tiap-tiap kartu, dan catatlah cara di mana kelas bekerja bersama dalam penugasan/penentuan.

g) Tunjukkan bahwa keterampilan tim yang positif yang ditunjukkan akan perlu bagi seluruh kelas ini karena pengajaran aktif akan mewarnai.

h) Guru dan siswa bersama-sama menyimpulkan pembelajaran.

Berdasarkan uraian di atas, maka peneliti melakukan penelitian tindakan kelas melalui implementasi true or false strategi dalam pembelajaran PAI. Tujuan penelitian ini meliputi: (1) meningkatkan partisipasi siswa kelas IV dalam diskusi untuk menjawab pernyataan dari guru pada pembelajaran PAI dengan Strategi True or False di SD 38 Sungai Limau; (2) meningkatkan partisipasi siswa kelas IV dalam mengemukakan pendapat pada pembelajaran PAI dengan Strategi True or False di SD 38 Sungai Limau; dan (3) meningkatkan partisipasi siswa kelas IV dalam menyimpulkan pelajaran pada pembelajaran PAI dengan Strategi True or False di SD 38 Sungai Limau. 


\section{METODOLOGI PENELITIAN}

Penelitian ini dilaksanakan di SD 38 Sungai Limau Kabupaten Padang Pariaman dengan pertimbangan: sekolah bersedia menerima inovasi pendidikan terutama dalam proses pembelajaran, peneliti bertugas pada SD tersebut. Subjek dalam penelitian ini adalah siswa kelas IV SD 38 Sungai Limau, yang jumlah siswanya 20 orang, terdiri dari 10 orang laki-laki dan 10 orang perempuan. Jenis penelitian ini adalah penelitian tindakan kelas yang meliputi tahap perencanaan, pelaksanaan, pengamatan, dan refleksi. Data penelitian berupa lembar observasi dan tes dari setiap tindakan perbaikan pembelajaran PAI dengan Strategi True or False siswa kelas IV SD yang diteliti. Data tersebut berisi tentang hal-hal yang berkaitan dengan perencanaan, pelaksanaan, dan hasil pembelajaran yang berupa informasi berikut: (1) Pelaksanaan pembelajaran yang berhubungan dengan perilaku guru dan siswa yang meliputi interaksi belajar mengajar antara guru dan siswa, siswa dengan guru dalam proses pembelajaran PAI; (2) Evaluasi pembelajaran PAI berupa evaluasi proses maupun evaluasi hasil; dan (3) Hasil tes siswa dilaksanakan sesudah pelaksanaan tindakan pembelajaran PAI.

Data penelitian diperoleh melalui observasi dan tes. Data yang diperoleh kemudian dianalisis dengan menggunakan pendekatan kualitatif dan kuatitatif karena peneliti ingin mengamati fenomena yang terjadi di dalam kelas. Indikator keberhasilan pada penelitian ini adalah apabila persentase partisipasi siswa dalam pembelajaran sudah masuk dalam kategori banyak yaitu $270 \%$. Siswa dikatakan tuntas belajar apabila telah mencapai acuan standar Kriteria Ketuntasan Minimal (KKM) yang ditetapkan oleh sekolah tempat penelitian yaitu 70, sedangkan indikator pada partisipasi siswa adalah:

1. Persentase partisipasi siswa dalam diskusi meningkat menjadi $\geq 70 \%$.

2. Persentase partisipasi siswa dalam mengemukakan pendapat meningkat menjadi $\geq 70 \%$.

3. Persentase partisipasi siswa dalam menyimpulkan pelajaran meningkat menjadi $\geq 70 \%$.

\section{HASIL DAN PEMBAHASAN PENELITIAN}

\section{A. Hasil Penelitian \\ 1. Siklus I \\ a) Tahap Perencanaan}

Pada tahap ini peneliti membuat persiapan untuk melaksanakan tindakan pada siklus I. Persiapan tersebut disusun dan diwujudkan dalam bentuk rencana pelaksanaan pembelajaran (RPP), pembuatan RPP ini disusun secara kolaboratif antara peneliti dan guru kelas IV berdasarkan program semester II sesuai dengan waktu penelitian berlangsung. Perencanaan pada siklus I ini disusun untuk 2 kali pertemuan (4 x 35 menit) dengan alokasi waktu 1 kali pertemuan 2 x 35 menit. Materi pembelajaran diambil berdasarkan KTSP 2006 Sekolah Dasar mata pelajaran PAI kelas IV. Buku panduan yang digunakan yaitu Buku Pendidikan Agama Islam kelas IV terbitan Erlangga. Materi pembelajaran pada pertemuan pertama siklus I adalah Malaikat dan tugasnyat. Standar Kompetensi pembelajarannya adalah "Mengenal malaikat dan tugasnya. Kompetensi Dasarnya adalah menjelaskan pengertian malaikat" dengan indikatornya yaitu: (1) Menyebutkan pengertian malaikat, (2) Mengidentifikasi malaikat, (3) Mengelompokkan malaikat, (4) Menyebutkan tugas malaikat. Untuk mencapai indikator tersebut peneliti menggunakan Strategi Aktif True or False dengan mengikuti langkah-langkah yang telah ditentukan. Adapun langkah-langkah pembelajaran dengan Strategi True or False pada pertemuan pertama ini peneliti wujudkan dalam RPP. Tahap-tahap kegiatan pembelajaran pada setiap pertemuan dalam RPP ini peneliti menjadi tiga tahap, yaitu: (1) kegiatan awal, (2) kegiatan inti, (3) kegiatan akhir. Ketiga tahap ini tidak berdiri sendiri, melainkan terkait dengan kegiatan satu dengan kegiatan yang lainnya.

\section{b) Tahap Pelaksanaan}

Pelaksanaan pembelajaran pada siklus I dilakukan dalam dua kali pertemuan. Proses pembelajaran terdiri atas kegiatan pembukaan, kegiatan inti, dan kegiatan penutup.

c) Tahap Pengamatan

Pengamatan (observasi) dilakukan untuk setiap kali pertemuan, yaitu mengisi lembar observasi partisipasi siswa dalam pembelajaran PAI dengan strategi True or False. Hasil analisis observer terhadap pelaksanaan pembelajaran menunjukkan bahwa pembelajaran yang peneliti laksanakan berlangsung kurang baik. Begitu juga halnya dengan pengamatan dengan pengamatan terhadap partisipasi siswa dalam pembelajaran yang belum optimal. Untuk lebih jelasnya, hasil observasi obsever terhadap partisipasi siswa di uraikan sebagai berikut:

1) Data Hasil Observasi Partispasi Siswa dalam Pembelajaran PAI

Hasil analisis observer terhadap partisipasi siswa dapat dilihat pada Tabel dibawah ini. 
Tabel 2

Persentase Partisipasi Siswa Kelas IV Pada Siklus I

\begin{tabular}{|c|c|c|c|c|c|}
\hline \multirow[t]{3}{*}{ Indikator } & \multicolumn{4}{|c|}{ Pertemuan } & \multirow{3}{*}{$\begin{array}{c}\text { Rata-Rata \% } \\
\text { Indikator }\end{array}$} \\
\hline & \multicolumn{2}{|l|}{$\bar{I}$} & \multicolumn{2}{|c|}{ II } & \\
\hline & Jumlah & $\%$ & Jumlah & $\%$ & \\
\hline 1 & 11 & $55 \%$ & 13 & $65 \%$ & $60 \%$ \\
\hline 2 & 9 & $45 \%$ & 11 & $55 \%$ & $50 \%$ \\
\hline 3 & 5 & $25 \%$ & 7 & $35 \%$ & $30 \%$ \\
\hline Jumlah siswa & 20 & & 20 & & \\
\hline $\begin{array}{l}\text { Keterangan: } \\
\text { Indikator } 1 \\
\text { Indikator } 2 \\
\text { Indikator } 3\end{array}$ & $\begin{array}{l}\text { Partisipas } \\
\text { Partisipas } \\
\text { Partisipas }\end{array}$ & $\begin{array}{l}\text { iswa } \\
\text { iwa }\end{array}$ & $\begin{array}{l}\text { lam me } \\
\text { lam me } \\
\text { am men }\end{array}$ & $\begin{array}{l}\text { ksanak } \\
\text { remuk } \\
\text { mpulk }\end{array}$ & $\begin{array}{l}\text { diskusi. } \\
\text { kan pendapat. } \\
\text { in pelajaran. }\end{array}$ \\
\hline
\end{tabular}

Berdasarkan Tabel 2, dapat dikemukakan persentase partisipasi siswa pada bagian yang diamati dan penjelasan sebagai berikut:

a. Persentase rata-rata partisipasi siswa dalam indikator saat melaksanakan diskusi adalah $60 \%$, berarti siswa sudah mulai bisa melaksanakan diskusi.

b. Persentase rata-rata partisipasi siswa dalam indikator saat mengemukakan pendapat adalah $50 \%$ berarti siswa sudah mulai berani dalam mengemukakan pendapat.

c. Persentase rata-rata partisipasi siswa saat menyimpulkan pelajaran adalah $30 \%$, berarti siswa sudah mulai bisa menyimpulkan pelajaran meski hanya sedikit.

Berdasarkan siklus I ini, telihat masih banyak siswa yang belum berpartisipasi dalam proses pembelajaran khususnya pada indikator 2 dan 3. Hal ini disebabkan strategi yang digunakan peneliti sangatlah berbeda dengan yang sebelumnya. Siswa masih menganggap strategi yang digunakan oleh peneliti dalam proses pembelajaran masih baru, sehingga siswa belum terbiasa dan terpartisipasi dalam proses pembelajaran dengan baik di dalam kelas sewaktu dengan strategi ini.

2) Data Hasil Observasi Aktivitas Guru dalam Proses Pelaksanaan Pembelajaran

Selanjutnya berkaitan dengan hasil pengamatan terhadap aktivitas guru dalam proses pelaksanaan pembelajaran pada siklus I, dapat dilihat pada dibawah ini.

Tabel 3

Persentase Aktivitas Guru Pada Siklus I

\begin{tabular}{lcl}
\hline Pertemuan & Jumlah skor & Persentase \\
\hline I & 12 & $60 \%$ \\
II & 14 & $70 \%$ \\
Rata-rata & & $65 \%$ \\
\hline
\end{tabular}

Dari Tabel 3 dapat dilihat dengan analisis pada persentase aktivitas guru dalam mengelola pembelajaran memiliki rata-rata persentase $65 \%$, sehingga sudah dapat dikatakan baik tetapi belum mencapai indikator keberhasilan $80 \%$.

3) Nilai Hasil Belajar pada Ulangan Harian (UH)

Berdasarkan hasil tes siklus I terkait ulangan harian (UH), persentase siswa yang tuntas UH dan ratarata skor tesnya dapat dilihat pada Tabel 4.

Tabel 4

Ketuntasan dan Rata-rata Hasil Belajar Siswa (UH) Pada Siklus I

\begin{tabular}{ccc}
\hline No & \multicolumn{1}{c}{ Uraian } & Jumlah \\
\hline $\mathbf{1}$ & Jumlah siswa yang mengikuti UH & 20 \\
$\mathbf{2}$ & Jumlah siswa yang tuntas & 8 \\
$\mathbf{3}$ & Jumlah siswa yang tidak tuntas & 12 \\
& Presentase ketuntasan & $40 \%$ \\
& Rata- rata nilai UH & 54,82 \\
\hline
\end{tabular}

Berdasarkan Tabel 4 terlihat bahwa persentase ketuntasan hasil belajar siswa pada UH secara keseluruhan masih tergolong rendah dan rata-rata nilai UH secara keseluruhan belum mencapai KKM yang 
ditetapkan. Dapat dijelaskan pada masing-masing data hasil belajar siswa yaitu: Nilai UH siswa yang terendah adalah 16 dan nilai UH siswa yang tertinggi adalah 85. Nilai siswa yang memperoleh nilai di atas KKM ada sebanyak 8 orang, sedangkan siswa yang memperoleh nilai di bawah KKM ada sebanyak 12 orang. Dalam target ketuntasan belajar yang ditetapkan oleh peneliti pada indikator keberhasilan ketuntasan belajar secara klasikal yaitu $70 \%$ dari jumlah siswa, sedangkan ketercapaian ketuntasan belajar pada siklus I ini belum mencapai target ketuntasan belajar, dan peneliti ingin meningkatkannya pada siklus II untuk mencapai target ketuntasan belajar secara klasikal.

\section{d) Tahap Refleksi}

Kegiatan refleksi dilakukan secara kolaboratif antara peneliti dan observer yang dilakukan pada setiap siklus berakhir. Siklus I ini mencakup refleksi terhadap perencanaan, pelaksanaan tindakan, observasi, evaluasi dan hasil yang diperoleh oleh siswa. Dari tahap perencanaan, peneliti mempersiapkan RRP ditambah dengan LKS, lembar observasi partisipasi belajar siswa, lembar aktivitas peneliti dalam proses pelaksanaan pembelajaran, dan tes hasil belajar siswa berupa UH. Dari pelaksanaan tindakan dan observasi pada siklus I, tingkat partisipasi siswa pada indikator partisipasi yang dilakukan oleh siswa masih sangat sedikit, ini terlihat pada indikator 2 dan 3. Peneliti bersama observer menyimpulkan masalah yang dihadapi peneliti dalam mengelola pembelajaran adalah peneliti masih terfokus pada kegiatan diskusi dan kurang maksimalnya peneliti dalam melakukan strategi True or False dalam pembelajaran PAI.

Melihat analisis tes hasil belajar siswa pada siklus I, dapat disimpulkan bahwa hasil belajar siswa belum tercapai target yang diinginkan. Persentase tersebut dapat dilihat dari siswa yang tuntas belajar masih di bawah $70 \%$ yaitu hanya $40 \%$. untuk mengatasi hal ini, yang perlu ditingkatkan adalah peneliti memberikan motivasi kepada siswa untuk lebih giat lagi dalam belajar sehingga partisipasi siswa untuk belajar melakukan diskusi secara kelompok atau berpasangan, mengeluarkan pendapat, dan menyimpulkan pelajaran. Ketika diskusi kelompok akan meningkat pada pembelajaran selanjutnya. Selain itu peneliti akan meningkatkan kemampuan siswa dalam mengemukakan pendapat ketika diskusi dengan cara kartu pernyataan yang telah mereka dapat sehingga partisipasi dalam mengemukakan pendapat dalam diskusi dapat dituangkan di depan kelas. Selain itu peneliti akan memaksimalkan waktu dalam proses pelaksanaan pembelajaran sesuai dengan RPP.

\section{Siklus II}

\section{a) Tahap Perencanaan}

Hasil analisis pada siklus I menunjukkan subjek penelitian belum mencapai tujuan pembelajaran yang diharapkan. Karena itu pembelajaran dilanjutkan dengan siklus II. Pembelajaran pada siklus II dilakukan agar siswa lebih terbiasa dengan strategi pembelajaran yang dilakukan yaitu pembelajaran PAI dengan menggunakan strategi True or False dalam meningkatkan partisipasi belajar siswa melalui kegiatan aktif dalam pembelajaran sehingga pembelajaran yang diberikan menjadi lebih bermakna.

\section{b) Tahap Pelaksanaan}

Sama dengan pelaksanaan siklus I, proses pelaksanaan siklus II terbagi menjadi dua kali pertemuan. Proses pembelajaran dibagi menjadi tiga, yaitu kegiatan awal, kegiatan inti, kegiatan akhir.

\section{c) Tahap Pengamatan}

Pengamatan (observasi) dilakukan untuk setiap kali pertemuan, yaitu mengisi lembar observasi partisipasi siswa dalam pembelajaran PAI dengan strategi True or False di kelas IV SD 38 Sungai Limau. Pada akhir siklus diberikan tes hasil belajar berupa ulangan harian. Hasil analisis observer terhadap pelaksanaan pembelajaran menunjukkan bahwa pembelajaran yang peneliti laksanakan berlangsung baik. Begitu juga halnya dengan pengamatan terhadap partisipasi siswa dalam pembelajaran. Untuk lebih jelasnya, hasil observasi observer terhadap partisipasi siswa diuraikan sebagai berikut:

\section{1) Data Hasil Observasi Partisipasi Siswa dalam Pembelajaran PAI}

Melalui lembar observasi partisipasi belajar siswa, yang digunakan untuk melihat proses dan perkembangan partisipasi yang terjadi selama pembelajaran berlangsung. Hasil analisis observer terhadap partisipasi siswa dalam pembelajaran dapat dilihat pada Tabel dibawah ini. 
Tabel 5

Persentase Partisipasi Siswa Kelas IV Pada Siklus II

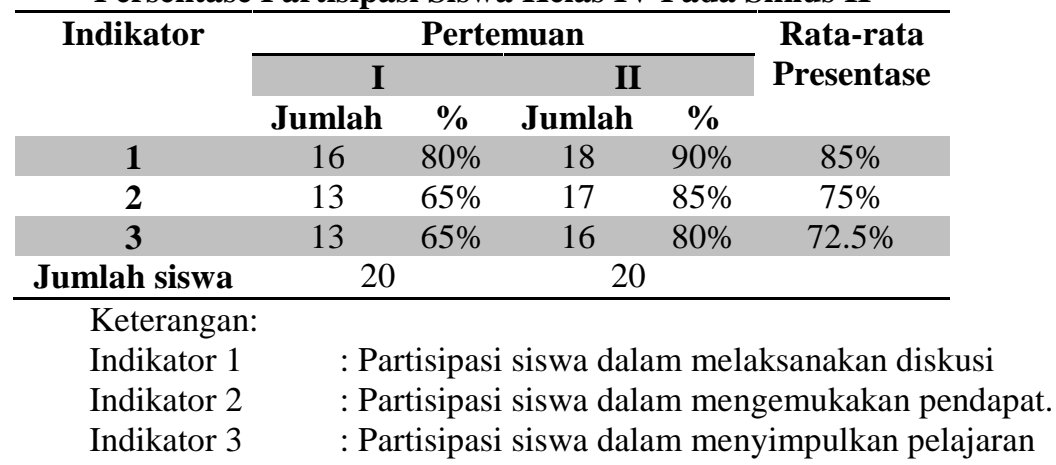

Berdasarkan Tabel 5, dapat dikemukakan persentase partisipasi siswa pada bagian yang diamati dan penjelasan sebagai berikut:

a) Persentase rata-rata partisipasi siswa dalam indikator diskusi adalah $85 \%$ berarti hampir semua siswa yang melaksanakan diskusi.

b) Persentase rata-rata partisipasi siswa dalam indikator mengemukakan pendapat adalah $75 \%$, berarti hampir semua siswa sudah bisa dan berani dalam mengemukakan pendapat.

c) Persentase rata-rata partisipasi siswa dalam menyimpulkan pelajaran adalah $72.5 \%$ berarti hampir semua siswa berpartisipasi menyimpulkan pelajaran.

Pada siklus II ini terlihat hampir semua siswa berpartisipasi dalam strategi True or False hal ini disebabkan siswa sudah mulai bisa melakukan setiap indikator yang ditetapkan oleh peneliti.

2) Data Hasil Observasi Aktivitas Guru dalam Proses Pembelajaran

Berdasarkan lembar observasi aktivitas guru dalam proses pelaksanaan pembelajaran pada siklus II, maka jumlah skor dan presentase aktivitas guru dalam mengelola pembelajaran pada siklus II dapat dilihat pada Tabel dibawah ini.

Tabel 6

Persentase Aktivitas Guru Pada Siklus II

\begin{tabular}{ccc}
\hline Pertemuan & Jumlah Skor & Persentase \\
\hline I & 15 & $75 \%$ \\
II & 18 & $90 \%$ \\
\multicolumn{2}{c}{ Rata-rata } & $83 \%$ \\
\hline
\end{tabular}

Data Tabel 6, dapat dilihat analisis pada persentase aktivitas guru dalam mengelola pembelajaran memiliki rata-rata persentase $83 \%$ sehingga sudah dapat dikatakan sangat baik dan telah mencapai indikator keberhasilan yang ditetapkan oleh peneliti.

3) Data Hasil Belajar pada Ulangan Harian (UH)

Berdasarkan hasil tes siklus II terkait ulangan harian (UH), persentase siswa yang tuntas UH dan ratarata skor tesnya dapat dilihat pada Tabel 7 berikut:

Tabel 7

Ketuntasan dan Rata-Rata Hasil Belajar Siswa (UH) Pada Siklus II

\begin{tabular}{cc}
\hline Uraian & Jumlah \\
\hline Jumlah siswa yang mengikuti UH & 20 \\
Jumlah siswa yang tuntas UH & 18 \\
Jumlah siswa yang tidak tuntas UH & 2 \\
Persentase ketuntasan UH & $\mathbf{9 0 \%}$ \\
Rata-rata nilai UH & $\mathbf{7 7 , 6 7}$ \\
\hline
\end{tabular}

Berdasarkan Tabel 7 terlihat bahwa persentase ketuntasan hasil belajar siswa pada UH secara keseluruhan sudah tergolong tinggi dan rata-rata nilai UH secara keseluruhan telah mencapai KKM yang ditetapkan. Dapat dijelaskan pada masing-masing data hasil belajar siswa yaitu: nilai UH yang terendah 50 dan nilai UH yang tertinggi 100 pada siklus II. Siswa yang memperoleh nilai di atas KKM ada sebanyak 18 orang, sedangkan siswa yang memperoleh nilai di bawah KKM ada sebanyak 2 orang siswa. Dalam target ketuntasan belajar yang ditetapkan oleh peneliti pada indikator keberhasilan ketuntasan belajar secara klasikal 
yaitu 70\% dari jumlah siswa, sedangkan ketercapaian ketuntasan belajar pada siklus II ini sudah mencapai target ketuntasan yang telah ditetapkan, bahkan melebihi yaitu $90 \%$ dari jumlah siswa yang mengikuti ulangan harian.

\section{d) Tahap Refleksi}

Hasil observasi didiskusikan dengan observer, tujuannya untuk mendapatkan gambaran tentang pelaksanaan tindakan pada siklus II. Berdasarkan gambaran yang diperoleh bahwa partisipasi belajar siswa pada indikator I, II, dan III mengalami peningkatan. Gambaran yang diperoleh dari aktivitas peneliti dalam proses pelaksanaan pembelajaran sudah sangat baik dari sebelumnya. Melihat analisis tes hasil belajar siswa pada siklus II, dapat disimpulkan bahwa hasil UH sudah tercapai target hasil belajar yang diinginkan, baik presentase ketuntasan belajar maupun rata-rata skor tes. Persentase tersebut dapat dilihat dari jumlah siswa yang telah tuntas belajar, yaitu di atas 70\%, dan rata-rata sudah di atas Kriteria Ketuntasan Minimal (KKM) yaitu 70 .

\section{B. Pembahasan}

Penelitian tindakan kelas ini terdiri dari dua siklus yang setiap siklusnya terdiri dari dua siklus yang setiap siklusnya terdiri atas 2 kali pertemuan dan 1 kali tes hasil belajar pada akhir siklus. Pelaksanaan pembelajaran yang dilaksanakan dengan strategi True or False. Penelitian ini menggunakan instrumen penelitian berupa lembar observasi partisipasi siswa, lembar observasi aktivitas guru, dan tes hasil belajar siswa berupa UH pada setiap akhir siklus. Pembelajaran dengan strategi True or False membuat siswa semangat dalam belajar kelompok. Dengan strategi True or False akan membuat siswa berani dan bisa mengemukakan pendapatnya serta menyimpulkan pembelajaran.

\section{Partisipasi Siswa dalam Pembelajaran}

Persentase rata-rata partisipasi siswa pada umumnya mengalami peningkatan. Pembelajaran dengan Strategi True or False dapat meningkatkan partisipasi belajar siswa ke arah yang lebih baik. Hal ini dapat dilihat persentase rata-rata partisipasi siswa pada Tabel 8 berikut:

\section{Tabel 8}

Persentase Rata-rata Partisipasi Belajar Siswa Pada Siklus I dan Siklus II

No Indikator Partisipasi Siswa

\begin{tabular}{|c|c|c|c|}
\hline & & Siklus I & Siklus II \\
\hline 1 & Siswa dalam melaksanakan diskusi & $60 \%$ & $85 \%$ \\
\hline 2 & Siswa dalam mengemukakan pendapat & $50 \%$ & $75 \%$ \\
\hline 3 & Siswa dalam menyimpulkan pembelajaran & $30 \%$ & $72.5 \%$ \\
\hline
\end{tabular}

Berdasarkan Tabel 8 dapat disimpulkan bahwa pembelajaran PAI dengan Strategi True or False yang dilaksanakan dapat meningkatkan partisipasi siswa dalam proses pelaksanaan pembelajaran. Hal ini terlihat adanya peningkatan rata-rata persentase untuk masing-masing indikator partisipasi siswa dari siklus I ke siklus II yaitu: indikator siswa dalam melaksanakan diskusi mengalami peningkatan dari $60 \%$ ke $85 \%$, indikator siswa berani dalam mengemukakan pendapat mengalami peningkatan dari $50 \%$ ke $75 \%$, untuk indikator siswa dalam menyimpulkan pelajaran mengalami peningkatan dari $30 \%$ ke $72.5 \%$.

Peningkatan partisipasi belajar siswa pada pembelajaran PAI dengan menggunakan strategi True or False ini, membuat siswa akan lebih semangat belajar diskusi secara kelompok. Peneliti dalam proses pelaksanaan pembelajaran sudah baik dalam melaksanakan keterampilan dalam berdiskusi sekaligus memberikan arahan kepada siswa untuk dapat mengemukakan pendapatnya serta menanggapi dan menyimpulkan pelajaran.

\section{Aktivitas Guru Dalam Proses Pelaksanan Pembelajaran}

Persentase rata-rata aktivitas guru dalam proses pelaksanaan pembelajaran terjadi peningkatan strategi True or False. Hal tersebut dapat dilihat pada Tabel 9 berikut:

\section{Tabel 9}

\begin{tabular}{cc} 
Persentase Aktivitas Guru Pada Siklus I dan Siklus II \\
\hline Siklus & Persentase \\
\hline I & $65 \%$ \\
II & $83 \%$ \\
Rata-rata & $74 \%$ \\
\hline
\end{tabular}

Dari Tabel 9 dapat disimpulkan bahwa pelaksanaan pembelajaran PAI dengan strategi True or False dapat meningkat aktivitas guru dalam proses pelaksanaan pembelajaran. Hal ini terlihat adanya peningkatan persentase aktivitas guru dalam proses pelaksanaan pembelajaran pada siklus I ke siklus II mengalami 
peningkatan dari $65 \%$ ke $83 \%$. Peningkatan aktivitas guru dalam proses pelaksanaan pembelajaran diebabkan peneliti sudah bisa melaksanakan pembelajaran PAI dengan strategi True or False.

\section{Hasil Belajar}

Data mengenai hasil belajar siswa diperoleh melalui tes hasil belajar di akhir siklus. Dalam hal ini terlihat peningkatan ketuntasan hasil belajar dari siklus I ke siklus II pada Tabel dibawah ini.

Tabel 10

Persentase Rata-rata Hasil Belajar Siklus I dan Siklus II

\begin{tabular}{ccc}
\hline Siklus & $\begin{array}{c}\text { Persentase Siswa yang } \\
\text { Telah Mencapai Nilai } \geq \mathbf{7 0}\end{array}$ & $\begin{array}{c}\text { Persentase Siswa yang } \\
\text { Belum Mencapai Nilai } \mathbf{5 0}\end{array}$ \\
\hline Siklus I & $40 \%$ & $60 \%$ \\
Siklus II & $90 \%$ & $10 \%$ \\
\hline
\end{tabular}

Berdasarkan Tabel 10 di atas, tentang hasil belajar siswa dalam 2 siklus, terlihat bahwa pada siklus I, siswa yang tuntas belajar $40 \%$ dan yang belum tuntas belajar $60 \%$, dengan nilai rata-rata secara klasikal $54,82 \%$. Sedangkan pada siklus II, siswa yang tuntas belajar $90 \%$ dan yang belum tuntas belajar hanya $10 \%$, dengan nilai rata-rata secara klasikal 77,5\%. Dengan demikian dapat disimpulkan bahwa persentase ketuntasan belajar siswa dari siklus I ke siklus II mengalami peningkatan dan sudah mencapai standar nilai KKM serta indikator keberhasilan secara klasikal yang terlihat pada tabel di atas.

Berdasarkan hasil analisis data di atas, dapat disimpulkan bahwa pembelajaran dengan strategi True or False dapat meningkatkan partisipasi dan hasil belajar PAI siswa karena peneliti memberikan suatu strategi dalam pembelajaran yang sangat menarik partisipasi belajar siswa, dalam partisipasi ini siswa dibuat dalam kelompok dan dari kelompok tersebut siswa belajar bersama-sama dengan teman-temannya, dari cara belajar siswa yang bersemangat akhirnya dapat meningkatkan hasil belajar PAI siswa kelas IV SD 38 Sungai Limau Kabupaten Padang Pariaman. Hal ini semakin menguatkan pendapat Zaini, dkk. (2005:24) yang menyatakan bahwa strategi True or False dapat mengajak siswa untuk terlibat ke dalam materi pelajaran dengan segera. Strategi ini menumbuhkan kerjasama tim, berbagi pengetahuan dan belajar secara langsung.

\section{KESIMPULAN DAN SARAN \\ KESIMPULAN}

Berdasarkan hasil penelitian dan pembahasan yang telah dipaparkan sebelumnya, maka peneliti menyimpulkan hal-hal sebagai berikut.

1. Peningkatan partisipasi siswa kelas IV SD 38 Sungai Limai pada pembelajaran PAI dengan strategi True or False pada siklus I, indikator siswa dalam melaksanakan diskusi $60 \%$ dan meningkat pada siklus II menjadi $85 \%$.

2. Peningkatan partisipasi belajar siswa kelas IV SD Negeri 27 Batang Anai pada pembelajaran PKn dengan strategi True or False, pada siklus I indikator partisipasi siswa dalam mengemukakan pendapat adalah $50 \%$ dan meningkat pada siklus II menjadi $75 \%$.

3. Peningkatan partisipasi belajar siswa kelas IV SD Negeri 27 Batang Anai pada pembelajaran PKn dengan strategi True or False, pada siklus I indikator partisipasi siswa dalam menyimpulkan pelajaran adalah $30 \%$ dan meningkat pada siklus II menjadi $72.5 \%$.

\section{SARAN}

Berdasarkan kesimpulan yang telah dicantumkan di atas, maka peneliti mengajukan beberapa saran untuk dipertimbangkan:

1. Bagi guru yang melaksanakan pembelajaran dengan strategi True or False dapat dijadikan salah satu strategi alternatif dalam pelaksaanaan pembelajaran PAI.

2. Guru sebaiknya membiasakan siswa untuk belajar secara diskusi agar siswa bisa mengeluarkan pendapatnya dan menyimpulkan pelajaran.

3. Bagi siswa, agar bisa membiasakan diri untuk dapat belajar secara diskusi, sehingga pemahaman iswa terhadap pembelajaran dapat meningkat.

\section{DAFTAR PUSTAKA}

Arikunto, Suharsimi, dkk. 2010. Penelitian Tindakan Kelas. Jakarta: Rineka Cipta

Desfitri, Rita, dkk. 2008. "Peningkatan Aktivitas, Motivasi dan Hasil Belajar Matematika Siswa Kelas VIII2 MTsN Model Padang melalui Pendekatan Kontekstual". Laporan Pengembangan Inovasi Pembelajaran di Sekolah (PIPS). Padang: FKIP Universitas Bung Hatta 
Dimyati, Mujiono. 2006. Belajar dan Pembelajaran. Cetakan ke-6. Jakarta: Rineka Cipta Muslich, Masnur. 2010. Pembelajaran Berbasis Kompetensi dan Kontekstual. Jakarta: Bumi Aksara

Nursidik, Yahya. 2008. “Metode Diskusi Pembelajaran”. Tersedia di http//www. Yahya nursidik.com. Diakses 04 Oktober 2012

Sanjaya, Wina. 2008. Strategi Pembelajaran Berorientasi Standar Proses Pendidikan. Jakarta: Kencana Prenada Media Grup

Silberman, Melvin. 2009. Active Learning. Bandung: Nusamedia dan Nuansa

Sudjana, Nana. 2005. Dasar-Dasar Proses Belajar Mengajar. Bandung: Sinar Baru Algasindo

Sumadi, Made. 2012."Partisipasi Belajar Siswa”. http: pawitriyadi87

Tukiran, Taniredja. 2010. Penelitian Tindakan Kelas. Bandung: Alfabeta

Wardani, I.G.A.K. 2003. Penelitian Tindakan Kelas. Jakarta: Pusat Penerbitan Universitas Terbuka Wiraatmadja, Rochiati. 2007. Metodologi Penelitian Tindakan Kelas. Bandung: Remaja Rosda Karya

Yusrizal. 2010. Bahan Ajar Pembelajaran PKn SD Kelas Tinggi. Padang: Jurusan PGSD Fkip Universitas Bung Hatta

Zaini, Hisyam, Bermawy Muntehe dan Sekar Ayu Aryani. 2005. Strategi Pembelajaran Aktif. Yogyakarta 